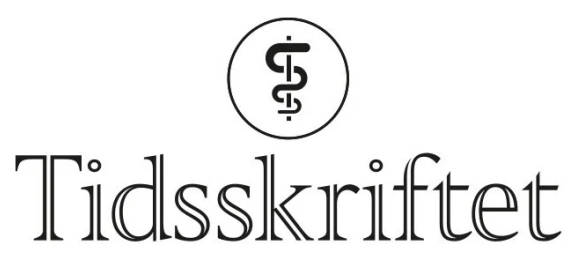

DEN NORSKE LEGEFORENING

\title{
Fremre skulderluksasjon - utredning og behandling
}

\author{
KOMMENTAR
}

\section{PER SUNDE}

persunde@persunde.no

Per Sunde er tidligere fastlege. I dag Skulderdiagnostikker ved Skulderklinikken.

Forfatteren har ikke oppgitt noen interessekonflikter.

Kaare Midtgaard og medarbeidere gir en god og nyttig oversikt over utredning og behandling av fremre skulderluksasjon i Tidsskriftet (1ํ). Det er gledelig å se at norske ortopeder er i front i utviklingen. Ettersom problemstillingene kan være mange og komplekse, finner jeg det hensiktsmessig å etterlyse noe mer informasjon og diskusjon om enkelte nøkkelpunkter.

Dagens konsepter utfordres nok noe ved at man etter første gangs luksering anbefaler tidligere og oftere stabiliseringsoperasjoner $(\underline{2}, 3,4$.). Jeg forstår det slik at man «skjærer gjennom» og oftere foreslår operasjon hos førstegangs lukserere pasienter under 30 år med førstegangs skulderluksasjon.

Eiji Itoi hevder at førstegangsluksering oftest ikke medfører kronisk instabilitet og anbefaler ofte å vente med stabiliserende prosedyrer til en eventuell annengangs luksering fordi man ellers risikerer å utføre unødvendig preventivstabiliserende kirurgi hos et betraktelig antall - særlig lavnivå-atleter (Invited special guest lecture: «Milestones in management of anterior shoulder instability» ved Berlin International Shoulder Course (BISC) 7-9 januar 2021). Jeg finner det hensiktsmessig her å minne om blant annet Hovelius' mange verdifulle bidrag og diskusjoner om når man bør operere eller ikke operere. Er pasienten 17 år, 25-30 år, eller eldre enn 30 år?

Med andre ord: skal man anbefale kirurgi til en ung forholdsvis ukomplisert førstegangslukserer, eller skal man fortsatt være litt tilbakeholden? Ikke minst etisk er disse overveielsene viktige. Det er ikke uten grunn at nesten alle større skulderortopedkonferanser i en årrekke har hatt «minibattles» om hva du gjør/ikke gjør med en førstegangs luksering - og dette notabene blant verdens fremste skulderortopeder. Noen entydig fasit har ingen - og iallfall ikke en ikke-ortoped som undertegnede. Det er som kjent nok av forsknings- og evidensutfordringer. Og hva er det naturlige forløpet etter en luksering? Hvor viktig er det å forsøke best mulig a reetablere den opprinnelige anatomien? Uansett vil best mulig kartlegging og utredning av den enkelte pasient ligge i bunn før beslutninger taes om kirurgi/ikke-kirurgi. 
Et lite hjertesukk tilslutt: jeg håper at tiden er forbi for følgende pasienthistorier: Førstegangs fremre skulderlukasjon hos en 5o-åring med en oversett massiv ledsagende cuffruptur. Dårlig resultat etter flere måneders trening. MR-resultat etter lang ventetid. Etter mange måneder er skulderen for dårlig til å kunne reddes fra å skulle trenge protese. I dag vet vi dertil at et slikt resultat kunne ha vært avverget ved en god rask der og da ultralydundersøkelse.

\section{LITTERATUR}

1. Midtgaard KS, Bøe B, Lundgreen K et al. Fremre skulderluksasjon - utredning og behandling. Tidsskr Nor Legeforen 2021; 141. doi: 10.4045/tidsskr.20.0826. [PubMed][CrossRef]

2. Provencher CMT, Midtgaard KS. Editorial commentary: Evidence to support surgical intervention for first-time shoulder instability: Stabilize them early. Arthroscopy 2020;36: 2533-6. [PubMed] [CrossRef]

3. Hurley E, Anil U, Lim Fat D et al. Operative treatment of anterior shoulder instability a network meta-analysis. Bull Hosp Jt Dis (2013) 2020; 78: 202-9. [PubMed]

4. Provencher MT, Midtgaard KS, Owens BD et al. Diagnosis and management of traumatic anterior shoulder instability. J Am Acad Orthop Surg 2021; 29: e51-61. [PubMed][CrossRef]

Publisert: 11. oktober 2021. Tidsskr Nor Legeforen. DOI:10.4045/tidsskr.21.0663

(C) Tidsskrift for Den norske legeforening 2023. Lastet ned fra tidsskriftet.no 26. april 2023. 